\title{
AN ANALYSIS OF LEARNING STEPS ON THE TEACHER'S LESSON PLAN BASED ON SCIENTIFIC APPROACH
}

\author{
Muawwinatul Laili ${ }^{1}$, Mufidatul Aliyah ${ }^{2}$ \\ ${ }^{1}$ Pendidikan Bahasa Inggris FKIP Universitas NU Sidoarjo \\ ${ }^{2}$ Pendidikan Guru Sekolah Dasar FKIP Universitas NU Sidoarjo \\ winalaily1984@gmail.com1.mufidatulailiyah321@gmail.com2
}

\begin{abstract}
Most of elementary school in Sidoarjo have already referred to the 2013 curriculum, one of them is MI Ma'arif Sambiroto. All teachers at MI Ma'arif Sambiroto have attended several trainings in designing lesson plans in accordance with the 2013 curriculum. However, the school has never conducted an analysis of the appropriateness of the learning steps on the teacher's lesson plans with a scientific approach. This research aims to describe the results of analysis of the appropiateness of the learning steps with the scientific approach and the appropiateness of the lesson plan's components according to the 2013 Curriculum. This research is a qualitative descriptive study that applies an interactive model. This research was conducted at MI Ma'arif Sambiroto, Taman, Sidoarjo. The subject in this research is the fourth grade teacher at MI Ma'arif Sambiroto and the main data is teacher's lesson plans. The data collection technique used by researcher is the documentation technique. The research instrument that used by the researcher is checklist sheet of the learning steps on lesson plan with scientific approach. The data analysis process starts from reviewing all the data from the documentation. Next, it is followed by the stage of reducing the data and presenting the result in brief descriptions. Last, is verifying the data to draw a conclusion. The result shows that the fourth grade teacher at MI Maarif Sambiroto has compiled the lesson plan components according to the 2013 curriculum but in first learning process to the fourth learning process, the teacher has not included a scientific approach in the learning steps of the lesson plan. But in the sixth learning process the teacher has not included scientific reasoning skills.
\end{abstract}

Keywords : Scientific approach; Lesson plan

Abstrak: Sebagian besar SD/MI di Sidoarjo sudah mengacu pada Kurikulum 2013 khususnya di MI Ma'arif Sambiroto, salah satunya adalah MI Ma'arif Sambiroto. Semua guru di MI Ma'arif Sambiroto sudah pernah mengikuti beberapa pelatihan tentang penyusunan RPP sesuai dengan kurikulum 2013. Tetapi pihak sekolah MI Ma'arif Sambiroto belum pernah melakukan analisis tentang kesesuaian langkah-langkah pembelajaran pada RPP guru dengan pendekatan saintifik. Penelitian ini bertujuan untuk mendeskripsikan analisis kesesuaian langkah-langkah pembelajaran dengan pendekatan saintifik dan analisis kesesuaian komponen RPP sesuai dengan Kurikulum 2013. Penelitian ini adalah penelitian deskriptif kualitatif yang menerapkan model interaktif. Penelitian ini dilaksanakan di MI Ma'arif Sambiroto Kecamatan Taman Kabupaten Sidoarjo. Subjek dalam penelitian ini adalah guru kelas IV di MI Ma'arif Sambiroto Kecamatan Taman Kabupaten Sidoarjo dan data utama penelitian ini adalah RPP guru. Teknik pengumpulan data menggunakan teknik dokumentasi. Instrumen penelitian yang digunakan adalah lembar checklist kesesuaian antara langkah-langkah pembelajaran di RPP guru dengan pendekatan saintifik. Proses analisis data dimulai dari menelaah seluruh data hasil dokumentasi. Setelah itu, dilanjutkan dengan mengadakan reduksi datadan menyajikan hasil dengan deskripsi yang jelas. Langah terakhir yaitu verifikasi untuk mengambil kesimpulan. Hasil penelitian menunjukkan bahwa secara keseluruhan guru menyusun komponen RPP sudah sesuai dengan Kurikulum 2013 tetapi pada RPP Pembelajaran 1 sampai dengan RPP Pembelajaran 4 guru belum merumuskan indikator pembelajaran aspek keterampiln sehingga guru tidak menyusun perencanaan penilaian 
autentik pada aspek keterampilan dan guru sudah mencantumkan pendekatan saintifik dalam langkah-langkah pembelajaran pada RPP, tetapi pada RPP Pembelajaran 6 guru belum mencantumkan keterampilan ilmiah menalar.

Kata kunci : Pendekatan Saintifik; Rencana Pelaksanaan Pembelajaran (RPP)

\section{INTRODUCTION}

A high qualified education is needed by every person of the nation because through qualified education, people can improve their welfare. Education also can make people more confident in expressing their skills and talent. Because of that, the education institution is expected to produce qualified graduates well. Since education in Indonesia refers to the Curriculum 2013 in the implementation of the curriculum of the participant students are trained to learn to observe, ask questions, collect data, analyze data, and communicate the learning outcomes approach called scientific. This approach needs to be done to train students to learn independently and think creatively. According to Januarta (2021: 2) in designing a lesson plan must be related to the education system that is implemented incuding the curriculum. In 2013 Curriculum, teachers need to have knowledge on how the application of the scientific approach suitability in designing of the lesson plan.

In appendix IV Permendikbud No. 81A / 2013 on Implementation of the General Education Curriculum Guidelines stated that Lesson Plan (RPP) is a plan of learning are developed in detail on a matter the subject or theme of a particular which refers to the syllabus. Meanwhile, in the attachment to Permendikbud number 65 of 2013 concerning process standards, it is stated that the RPP is a learning activity plan for one or more meetings. RPP is prepared based on KD or learning sub-themes for one or more meetings developed from the learning syllabus. At the Elementary school level is a suitable starting stage for children to think critically, creatively, independently, and innovatively because at that time children must focus on developing attitudes and behaviors. Therefore, it is hoped that the implementation of the 2013 Curriculum can be comprehensive in its application in schools, especially the Elementary level in Sidoarjo so that the development stage of students' attitudes and behavior can be maximized. Students must be guided to recognize their own potential from an early age and develop this potential with the help of teachers so that they become a generation capable of providing good feedback for the progress of the Indonesian State.

According to Fatchurrohman (2014: 47) learning that applies a scientific approach is a learning process designed in order to make students are more active and able to construct concepts, laws or principles through five main activity stages, namely; observing, asking, experimenting, associating, and communicating. The scientific approach encourages students to understand various materials, and obtain information from various sources. In applying scientific approach, it is necessary to apply research-based learning (discovery / inquiry learning). In the way of reasoning and critical attitude of students needed for search or discovery. Therefore, the scientific approach generally consists of activities to collect data or facts through observation and experimentation, then continue to formulate problems and hypotheses.

From this description it can be concluded that the principle of the scientific approach in learning activities is learning that encourages students to think actively and always gives students the opportunity to express their opinions and motivate teachers to improve their teaching quality. According to Dyer (2011: 23-24) the scientific approach has components of the learning process, including: observing, asking questions, gathering information, reasoning, and communicating. The following is an explanation of each activity carried out in scientific learning: 


\section{1) Making observations or observing}

Observation is using the five senses to obtain information. An object can be observed to determine its characteristics. For example: color, shape, temperature, volume, weight, smell, sound, and texture. Objects can show different characteristics if they are exposed to environmental influences. Human behavior can also be observed to determine traits, habits, responses, opinions, and other characteristics.

\section{2) Asking Questions}

Students need to be trained to formulate questions related to the material to be studied. This learning activity is very important to increase the curiosity of students and develop their abilities for lifelong learning. Teachers need to ask questions in an effort to motivate students to ask questions. One way to train students in asking questions is to display a phenomenon and ask students to ask questions related to it.

\section{3) Gathering Information}

Teachers can assign students to collect data or information from various sources, for example in language lessons and social science group lessons. Teachers need to direct students in planning activities, carrying out activities, and reporting on activities that have been recognized.

\section{4) Associate or Reason}

Information obtained from observations or experiments carried out must be processed to find the relationship between one information and another. The basis for processing information based on the scientific method is empirical reasoning. Empirical reasoning is based on inductive logic, namely reasoning from the specific to the general. Inductive reasoning uses specific evidence such as facts, data, information, and opinions from experts. Conclusions are made on the basis of this empirical evidence.

\section{5) Developing Networks and Communicating}

The ability to build networks and communicate needs to be possessed by students because this ability is as important as knowledge, skills and experience. Collaborating between groups is one way to form the ability of students to be able to build networks and communicate. Every student needs to be given the opportunity to talk with other people, make potential friendships, get to know people who can provide advice or information, and be known by others.

Most of the elementary schools (SD / MI) in Sidoarjo, have implemented the 2013 curriculum and one of them is MI M'arif Sambiroto, Sidoarjo. Based on the interview with a teacher of IV-A grade at MI Ma'arif Sambiroto, that school has never conducted an analysis focus on the implementation of scientific approach reflected on teacher's lesson plan although most of the teachers have joined some workshops on designing lesson plan in 2013 curriculum. In fact, the teacher states that they are confused in integrating the scientific approach in the learning steps. Based on the description, the purpose of this research is to describe how the scientific approach is reflected by teacher in learning steps of a lesson plan. In addition, the result of this research can be an evaluation for the school regarding to the teachers' quality in designing lesson plan.

The researcher used some previous studies in conducting this research, they are: a research conducted by Nugroho (2019) entitled "Analisis Rencana Pelaksanaan Pembelajaran Mata Pelajaran PJOK SD Negeri Kelas V Se-Kecamatan Pakem Kabupaten Sleman Ditinjau Dari Metode Saintifk". Second, a research that conducted by Amakae (2015) entitled "Analisis Proses Perencanaan Pembelajaran Tematik Menggunakan Pendekatan Saintifik di SD Negeri Monggang, Sewon, Bantul Yogyakarta". Both of studies have similarity with this research that is focus on 
lesson plan analysis based on scientific approach. In other side, there are differences between the previous studies and this research, they are; the learning materials or themes which included on lesson plan and the number of lesson plan that is analyzed by the reseacher.

\section{METHODS}

In this research, the researcher prefers to use qualitative methods. Qualitative methods is a source of well-founded, detailed descriptions and explanations of human processes, using qualitative data. It is possible to preserve chronological flow, see what events have contributed to what effects and extract fruitful explanations (Miles and Huberman, 2014: 2). The researcher applied the interactive model by Miles and Huberman to analyze the data.

The research subject is a teacher who compiled lesson plans at IV-A grade of MI Ma'arif Sambiroto, Sidoarjo Regency. The main data were three teacher's lesson plans of IV A grade. Data collection technique that used by the researcher is documentation technique. Researcher chose this technique because this technique makes it easier for researcher to collect the required data. The documents needed by researcher in research is teacher's Lesson Plan on Theme 6: "Citacitaku", Sub Theme 2 "Hebatnya Cita-citaku" which has been made by the teacher of IV A in MI Ma'arif Sambiroto. The lesson plan analyzed by the researcher in order to obtain information about the appropriateness of the lesson plan component formulation with a scientific approach. Based on data collection techniques, the research instruments used in this study were the component checklist sheet of the appropriateness between learning steps on lesson plan and scientific approach. The checklist sheet adopted from Eka (2020: 1-2) and the Document Analysis Format adopted from Ichsani (2014: 109-113).

Researcher used the Interactive Model by Miles and Huberman (2014) to analyze the data. According to Miles, Huberman, and Saldana (2014: 11) the data analysis process in qualitative research is carried out by stages: data collection; data condensation; data display; and drawing conclusions. The explanation of each stages are; a) Collecting data (Data Collection) is an activity of compiling instruments to obtain data in the field in a systematic way, b) Data condensation refers to the process of selecting, simplifying, abstracting, and or transforming data that approximates all parts of written field notes, interview transcripts, documents, and other empirical materials, c) Data display is an organization, a collection of information that allows inference and action. Presentation of data helps in understanding what is happening and for doing something, including deeper analysis or taking action based on understanding, d) Drawing conclusion and verification is the conclusion of the data analysis.

This model is a continuous, interactive, and continuous effort in the process of analyzing data. Data condensation, data presentation, and drawing conclusions will illustrate success in sequence as a series of data analysis as illustrated in the following figure:

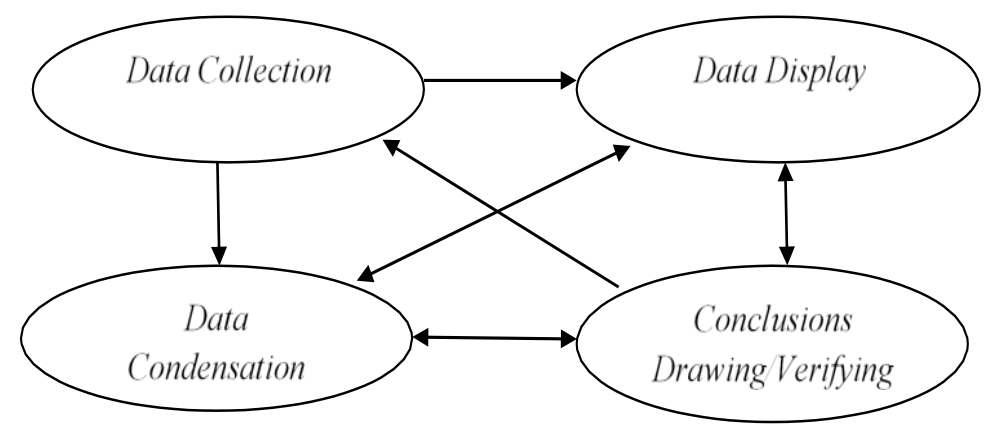

Figure 1.1 the stages of data analysis in Interactive Model 


\section{RESULTS}

The research data were obtained using the documentation method. Then the research results are analyzed by the researcher using qualitative descriptive techniques which means that the researcher will describe, explain and formulate all the collected data so that they are able to obtain a general and comprehensive picture. The researcher has analyzed the data in the form of 3 lesson plans compiled by the fourth grade teacher at MI Ma'arif Sambiroto. The results of the analysis are:

\section{Analysis of lesson plan 1}

Based on the results of the research instrument, the researcher finds the result of the lesson plan's components analysis of IV grade on theme 6 "Cita-Citaku", sub theme 2 "Hebatnya citacitaku", Learning 1 is as follows:

The identity of the subjects as a whole is complete, namely there is an educational unit, class, semester, subject / subject theme / sub- theme, number of meetings;

The formulation of indicators is in accordance with the competence and knowledge aspects, but the teacher has not included the suitability of the formulation of indicators with the aspects of skills, operational verbs in accordance with the competence measured;

The learning objectives are in accordance with the indicators and aspects of Audience, Behavior, Condition, and Degree;

The selection of teaching materials is arranged coherently and in accordance with the learning objectives and the character of students;

Selection of learning resources in accordance with learning objectives, learning materials, scientific approaches, and characteristics of students.

Selection of learning media in accordance with the learning objectives, learning materials, and characteristic of the students;

The learning method is in accordance with the learning objectives, scientific approach, and the characteristic of the students;

Scenario featuring activities preliminary study, core, and cover with clear and in accordance with the method of learning, the approach scientific, time allocation preliminary activities, core activities, and cover activities in accordance with the scope of the material;

Form of the authentic assessment draft accordance with the indicators of achievement of competencies that include assessment attitude and assessment aspects of knowledge but does not include assessment skills.

1) While the results of the analysis of the scientific approach to the teacher's lesson plan for IV grade focus on theme 6 "Cita-Citaku", sub theme 2 "Hebatnya Cita-Citaku", Lesson 1 is as follows :

1) The teacher has written the scientific skills of observing aspects on the steps of learning in the lesson plan. In the aspect of observing the teacher encourages students to read the text reading presented at Student Book;

2) The teacher has written the scientific skills aspects propose the steps of learning in the lesson plan. In the aspect ask the teacher invites students to ask responsible about the materials that is learned;

3) The teacher has included the scientific aspect of reasoning skills in the learning steps in the lesson plan. In the aspect of reasoning teachers encourage students to learn poems poem by answering questions from the students' book then the students write a conclusion about the results of observation; 
4) The teacher has written the scientific skills aspects of trying on measures of learning in the lesson plan. In the aspect of trying teachers encourage students to search for information about the cycle of life the two tails of animals who are different;

5) The teacher has included the scientific skills in the aspect of forming a network in the learning steps in the lesson plan. In the aspect of networking among teacher invites students collectively together to make a conclusion the results of learning during the day.

\section{b. Analysis of lesson plan 2}

Based on the results of the research instrument, the results of the analysis of the components of the lesson plans for IV grade theme 6 "Cita-citaku", sub theme 2 "Hebatnya Citacitaku", teaching learning 2 are as follows:

1) The identity of the subjects as a whole is complete, namely there is an education unit, class, semester, subject / subject / sub-theme, number of meetings.

2) The formulation of indicators is in accordance with the competence and knowledge aspects, but the teacher has not included the suitability of the formulation of indicators with the aspects of skills, operational verbs in accordance with the competence measured;

3) The learning objectives are in accordance with the indicators and aspects of Audience, Behavior, Condition, and Degree;

4) The selection of teaching materials is arranged coherently and in accordance with the learning objectives and the character of students;

5) Selection of learning resources in accordance with learning objectives, learning materials, scientific approaches, and characteristics of students;

6) Selection of learning media in accordance with the learning objectives, learning materials, and characteristics of students;

7) The learning method is in accordance with the learning objectives, scientific approach, and the characteristics of students;

8) The learning scenario displays preliminary, core and closing activities clearly and is in accordance with the learning method, scientific approach, systematic, and time allocation for preliminary activities, core activities, and closing activities according to the scope of the material;

9) The form of the authentic assessment is designed by teacher in accordance with the indicators of competency achievement which includes attitude assessment and knowledge aspect assessment but does not include skills assessment.

Based on the results of these research instruments, the results of the analysis of the scientific approach in the lesson plan of IV grade theme 6 "Cita-citaku", sub theme 2 "Hebatnya Citacitaku", Learning 1 are as follows:

1) The teacher has included the scientific skills in the aspect of observing the learning steps in the lesson plan. In the aspect of observing the teacher encourages students to read the text entitled "Kisah Seorang Penari Gandrung Banyuwangi";

2) The teacher has included the scientific skills of the questioning aspects of the learning steps in the lesson plan. In the questioning aspect, the teacher invites students to ask questions about the materials being studied;

3) The teacher has included the scientific aspect of reasoning skills in the learning steps in the lesson plan. In the aspect of reasoning, the teacher encourages students to express their 
understanding of the reading by making a mind map that explains the benefits of plants and animals in human life;

4) The teacher has included the scientific skills of the trying aspects of the learning steps in the lesson plan. In the aspect of trying, the teacher encourages students to try to imitate some dance movements;

5) The teacher has included the scientific skills in the aspect of forming a network in the learning steps in the lesson plan. In the aspect of forming a network, the teacher invites students together to make conclusions about learning outcomes for a day.

\section{c. Analysis of lesson plan 3}

Based on the results of the research instrument, the results of the analysis of the components of the lesson plan of IV grade theme 6 "Cita-citaku", sub theme 2 "Hebatnya Cita-citaku", Teaching 3 are as follows :

1) The identity of the subjects as a whole is complete, namely there is an educational unit, class, semester, subject / subject theme / sub-theme, number of meetings;

2) The formulation of indicators is in accordance with the competence and knowledge aspects, but the teacher has not included the suitability of the formulation of indicators with the aspects of skills, operational verbs in accordance with the competence measured;

3) The learning objectives are in accordance with the indicators and aspects of Audience, Behavior, Condition, and Degree;

4) The selection of teaching materials is arranged coherently and in accordance with the learning objectives and the character of students;

5) Selection of learning resources in accordance with learning objectives, learning materials, scientific approaches, and characteristics of students;

6) Selection of learning media in accordance with the learning objectives, learning materials, and characteristics of students;

7) The learning method is in accordance with the learning objectives, scientific approach, and the characteristics of students;

8) The learning scenario displays preliminary, core, and closing activities clearly and in accordance with the learning method, scientific approach, systematics, and time allocation for preliminary activities, core activities, and closing activities according to the scope of the material;

9) The form of the authentic assessment design is in accordance with the indicators of competency achievement which includes attitude assessment and knowledge aspect assessment but does not include skills assessment.

Based on the results of these research instruments, the results of the analysis of the scientific approach in the lesson plan of IV grade theme 6 "Cita-citaku", sub theme 2 "Hebatnya Citacitaku", learning 3 are as follows:

1) The teacher has written the scientific skills of observing aspects on the steps of learning in the lesson plan. In the aspect of observing the teacher, encouraging students to observe and read poem under the title "Mahapatih Gajah Mada"; 
2) The teacher has written the scientific skills aspects propose the steps of learning in the lesson plan. In the aspect ask the teacher invites students to ask responsible about the material that is learned;

3) The teacher has included the scientific aspect of reasoning skills in the learning steps in the lesson plan. In the aspect of reasoning teachers encourage learners to process the information that the participant students get in the form of a chart such as that presented in the students' book;

\section{DISCUSSION}

In this discussion, the researchers describes the results of the lesson plan analysis in accordance with the research problem and the research objectives regarding to the lesson plan's component and the suitability of the learning steps reflected on the teacher's lesson plan of IV grade with the scientific approach. In aspects of the lesson plan components, the data shows that the lesson plan for learning 1 to learning 3 are complete and in accordance with the instrument aspects of lesson plan components. In addition, the result of the conformity of learning steps on six lesson plans with scientific approach shows that the teacher is already understand the notion of integrated thematic learning. It reflected by the activities of learning in the lesson plan 1 until the lesson plan 6 which design in sequence and appropriate with basic competencies, learning indicators, and learning objectives. However, the teacher has not formulated indicators with aspects of skills in Lesson Plan of Learning 1 to learning 3 so that the teacher also does not develop an authentic assessment design based on the skills aspect.

According to the analysis of conformity of learning steps on lesson plan with scientific approach, the result shows that the teacher of IV grade at MI Ma'arif Sambiroto has included the scientific approach in every activity on his lesson plan. It was proved by the activities on lesson plan 1 to 3 which use the learning method with a scientific approach. In terms of the suitability of the learning steps in the lesson plan with the scientific approach, as a whole it is in accordance with the scientific skills of observing, questioning, reasoning, trying, and networking. Based on the discussion, the research result shows that all of learning activities on IV grade teacher's lesson plans are appropriate with scientific approach.

Compared with the previous research conducted by Nugroho (2019) which studied on PJOK subject's lesson plan that analyzed using scientific approach. He found that the percentages of the appropriateness between learning activities and scientific approach is $43,75 \%$ that is categorized "enough". It means that only some activities on the lesson plan that reflects the scientific approach. In addition, the result of a research by Amakae (2015) which studied on lesson plan analysis of thematic learning in Elementary school using scientific approach. She found that the teachers have been integrated the each step of scientific approach in every activity on lesson plan, including; observing, questioning, experimenting, associating, and communicating. It can be assumed that the teacher is understand well about applying scientific approach of the learning activities included on lesson plan.

\section{CONCLUSIONS AND SUGGESTIONS}

Based on the research findings and discussion in the previous chapter, it can be concluded that overall the components of lesson plan 1 to lesson 3 are in accordance with the 
lesson plan components that included on research instrument. However, the lesson plan of learning 1 to 3 the teacher has not formulated indicators based on the skills aspect. It caused the teacher did not insert skill assessment on teacher authentic assessment. In addition, overall the fourth grade teacher at MI Ma'arif Sambiroto has been included the scientific approach in designing the lesson plans. It can be proven by the learning steps on the lesson plan of learning 1 to lesson plan of learning 3 include scientific approach steps.

The researcher gives some suggestions regarding to the research result. First, the teacher should be consistent in deciding the completeness of lesson plan components and it must be in accordance with the curriculum in 2013, especially in terms of the formulation of indicators. Additionally, teachers should consistently include the skills of scientific observe, ask, to reason, to try and form a network on the steps of learning the lesson plans and lists all the indicators of learning approaches scientifically into learning steps on teacher's lesson plan so learning activity becomes more effective. Second, the headmaster of the school should conduct an evaluation and training for teachers on the preparation of lesson plans' component curriculum in 2013 to improve the ability of teachers in preparing lesson plans in accordance with the rules that are in the curriculum of 201. Based on the limitation of this research that is only focus on lesson plan analysis, the researcher suggest the next researchers to .conduct a deeper analysis on learning activities in the classroom based on scientific approach including the teachers' and students' activities during the learning process.

\section{REFERENCES}

Amakae, Indah Haryati. 2015. Analisis Proses Perencanaan Pembelajaran Tematik Menggunakan Pendekatan Saintifik di SD Negeri Monggang, Sewon, Bantul

Dyer, J., Gregersen, H., \& Christensen, C.M. 2011. The Innovator's DNA. Boston: Harvard Business Review Press.

Eka, Rizky. Format Telaah RPP No Komponen Rencana Pelaksanaan Pembelajaran.(https://www.academia.edu/9936747/Format_Telaah_RPP

_No_Komponen_Rencana_Pelaksanaan_Pembelajaran, diakses 14 April 2020)

Fatchurrohman. 2014. Pembelajaran Tematik Integratif Konsep Dasar dan Aplikasi. Salatiga: PIP STAIN Yogyakarta. Skripsi. Jurusan Pendidikan Guru Sekolah Dasar Universitas Negeri Yogyakarta

Ichsani, Annisa Nadya Amalia. 2014. Implementasi Pembelajaran Dengan Pendekatan Scientific Pada Kelas IV Di SD Negeri I Manyaran, Wonogiri. Skripsi. Jurusan Pendidikan Prasekolah dan Sekolah Dasar Universitas Negeri Yogyakarta

Januarta, Putu, A., Utami, L.K., \& Utami, Ida, A. 2021. Experienced English Teachers' Perspectives on the Fulfillment of one-page Lesson Plan Principles at SMAN 1 Singaraja. Education and Human Development Journal (EHDJ). Vol. 6 (1)

Kemendikbud. 2013. Permendikbud Nomor 65 Tahun 2013 Tentang Standar Proses Pendidikan Dasar dan Menengah. Jakarta: Kemendikbud

Kemendikbud. 2013. Permendikbud Nomor 81A Tahun 2013 Tentang Implementasi Kurikulum. Jakarta: Kemendikbud

Miles, Huberman, Saldana. 2014. Qualitative Data Analysis A Methods Sourcebook. America: SAGE Publication, Inc

Nugroho, Nanda Wiji. 2019. Analisis Rencana Pelaksanaan Pembelajaran Mata Pelajaran PJOK SD Negeri Kelas V Se Kecamatan Pakem Kabupaten Sleman Ditinjau Dari Metode Saintifk. Skripsi. Jurusan Pendidikan Guru Sekolah Dasar Penjas Universitas Negeri Yogyakarta. 